\title{
Macroeconomic Determinants of Urbanization in Pakistan
}

\section{Muhammad Afzal ${ }^{\star}$ Sheikh Shoaib Ahmed ${ }^{2}$ Mustansar Nawaz ${ }^{3}$}

Department of Economics, Preston University, Islamabad-Pakistan ${ }^{2}$ Email:profafzal@gmail.com Tel: +92-333-9982533

Email:mustansar636@yahoo.com Tel:+92-331-5064949

${ }^{2}$ Department of Management Sciences, Preston University, Islamabad-Pakistan

'Email:shoaibusman81@gmail.com Tel.+92-334-6881820

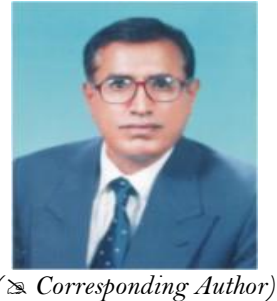

( Corresponding Author)

\begin{abstract}
Urbanization refers to the migration of rural people to urban centers in search of better jobs. Urbanization and growth go together; no country has ever reached middle-income status without a significant population shift into cities. Urbanization has strong association with unemployment, economic growth, poverty, infrastructure, crimes, health, socio-economic conditions and education. In 2050, most of the urban population of the world will be concentrated in Asia (52\%) and in Africa (21\%). A simple and modest model provided reasonable results. Increase in literacy is a decisive factor that has significant impact on increasing urban population. Per capita GDP growth also positively influences the urban population. Age-structure is too an important determinant of migration and urbanization. It is an open secret that generally young persons have gone abroad. Specification and diagnostics test supported the model which reveals appropriateness and statistical soundness of the model. Serious heed is paid to delimitation of cities to make them manageable and governable. Agriculture is provided sufficient resources to discourage migration to cities.
\end{abstract}

Keywords: Urbanization, Pakistan, Macroeconomic, Determinants, Migration, Unemployment

JEL Classification: C20, J100, O11.

Citation | Muhammad Afzal; Sheikh Shoaib Ahmed; Mustansar Nawaz (2018). Macroeconomic Determinants of Urbanization in Pakistan. Growth, 5(1): 6-12.

History:

Received: 20 September 2018

Revised: 22 October 2018

Accepted: 27 November 2016

Published: 24 December 2018

Licensed: This work is licensed under a Creative Commons Attribution 3.0 License (oc)

Publisher: Asian Online Journal Publishing Group
Contribution/Acknowledgement: All authors contributed to the conception and design of the study.

Funding: This study received no specific financial support

Competing Interests: The authors declare that they have no conflict of interests.

Transparency: The authors confirm that the manuscript is an honest, accurate, and transparent account of the study was reported; that no vital features of the study have been omitted; and that any discrepancies from the features of the study have been omitted;
study as planned have been explained.

Ethical: This study follows all ethical practices during writing.

\section{Contents}

1. Introduction

2. Significance of Study

3. Literature Review

4. Model and Data. .8

9

5. Empirical Results.

6. Conclusion 


\section{Introduction}

Urbanization is narrowly associated with the development of an economy. When an economy develops, the relative and absolute changes in urbanization, unemployment, literacy rate, energy demand are seen. A developing economy always tries to get a sustainable high level of employment and literacy rate etc. History shows that human population has been moving from one city to another city or from country to another due to social, economic, political and religious reasons. Migration is a global phenomenon and its dynamics and determinants change over time. History is replete with examples. Muslims migrated from Mecca to Medina because of persecution by the people of Mecca.

After oil price hike of 1973 and second oil price increase in 1979, petrodollars were accumulated by oil exporting Middle East countries which were channeled to USA and European banks. Massive increase in oil prices resulted in unmanageable balance of payments (BoPs) deficit particularly for developing countries. These countries had to borrow from USA and European banks to meet BoPs deficit that later culminated in debt-crisis in 1980s. On the other hand, many job opportunities were opened in the oil exporting countries that attracted both skilled and unskilled labor from developing countries. Increase in remittances was a natural consequence of migration to oil exporting countries that certainly provided BoPs respite (Todero and Smith, 2012). The urbanization cannot be stopped because no country can afford to have a break in the growth and economic development. Urbanization refers to the migration of rural people to urban centers in search of better jobs because employment opportunities are concentrated in the big urban centers and thus migration has become a very complex dilemma of development process

Studies argue that urbanization and growth go together; no country has ever reached enviable economic growth without a significant population shift into cities. Urbanization is compulsory to sustain growth in developing nations. It has also been linked to social and environmental problems and to perceived mismatches between population distributions and economic development. Kasarda and Crenshaw (1991)say that urbanization has strong association with unemployment, economic growth, poverty, infrastructure, crimes, health, socioeconomic conditions and education. Among these factors some affect positively and some negatively. Urbanization affects the economy, agricultural land becomes under pressure when more and more urbanization takes place.

\subsection{Global Trends of Urbanization}

Between 1950 and 2003 the world urban population increased four times. on the other hand, world rural population increased less than doubled from 1.8 billion to 3.2 billion between 1950 and 2000 (Cohen, 2006). The world's urban population is now near to 3.9 billion and is expected to reach 6.3 billion in 2050 . Today 53 percent of population is living in urban areas in the world. Europe has the second highest share of the world's urban population, at 14 per cent, followed by Latin America and the Caribbean with 13 per cent. Over the next four decades, Africa and Asia will experience a marked increase in their urban populations. By mid-century, the urban population of Africa is likely to triple and that of Asia to increase by 61 per cent. As a consequence, close to 90 per cent of the increase in the world's urban population will take place in the urban areas of Africa and Asia. In 2050, most of the urban population of the world will be concentrated in Asia (52 per cent) and Africa 21 per cent (United Nations, 2014).

\subsection{Urbanization in Pakistan}

In Pakistan the issue of urbanization has received limited attention. Pakistan is one of the fastest urbanizing countries in South Asia and the share of urban population has increased from 17 percent in 1951 to 37 percent in 2010 and projections shows that in the next 10 to 15 years half of the population will be living in urban areas of Pakistan (Hussain, 2014). According to United Nations (2006) projections for Pakistan, in 2025 half of total population will be dweller in cities.

Many cities of Pakistan are overburdened due to high population growth and rapid growth of urbanization, which is causing administrative problems and social issues like education, health facilities, housing problems etc. According to Afzal and Awais (2014) dramatic social changes have led to rapid urbanization and emergence of the megacities. During 1990-2003 Pakistan achieved the highest level of urbanization growth in history and become second most urbanized in country in South Asia.

The main reasons of the urbanization in Pakistan are: unemployment, high growth rate of population, and backwardness of rural areas since rural areas lack civil amenities. People migrate to cities in search of better job opportunities and moderate supply of education, health, transportation facilities. Urbanization growth seems to be a major cause of environmental degradation. Current population growth and development of the so-called residential colonies have adversely affected the supply of arable land and obviously food production cannot keep pace with increasing number of people. Sustainable economic development means that reasonable economic growth is achieved without compromising the environment and future of the coming generations. High population growth and massive urbanization have jeopardized the wellbeing of the future generations.

Different studies have been done on urbanization issue in Pakistan. Jalil and Iqbal (2010) have argued that the urbanization encourages crimes as the rate of crime is higher in large cities and in urbanized areas. They find association between the crime rate and urbanization in Pakistan for the period 1964-2008. Arif and Ibrahim (1998) used 1998 census data to investigate urban population growth, pace of urbanization and components of urban growth for the period 1981-98. The population living in urban areas has increased substantially during the last 50 years. The urban population in 1998 exceeded the total population of the country at the time of Independence.

Poverty is associated with unemployment which is a big hurdle for growth of any economy. High rate of unemployment attracts the jobless people to move to places where the job opportunities are high. Shahbaz et al. (2010) examined the relationship between urbanization and poverty. Empirical analysis shows strong evidence of the fact that in Pakistan, poverty is mostly influenced by increasing macroeconomic shocks and the relationship between the two is positive.Farah et al. (2012) examined the migration behavior of the people in the wake of 
changing patterns of socio-economic and demographic structure. Results shows that pull factors, like job opportunities in cities, education, and health are major components of migration to urban centers from rural areas.

According to Todero and Smith (2012) the positive relationship between urbanization and per capita income is one of the most logical and valid facts of the development process. Generally, the more developed, the country is (measured by per capita income), there is a greater share of population living in urban areas. Countries with high GDP per capita are most urbanized countries. Similarly the poorest countries are among the least urbanized. The fast growth of cities in developing countries is the most important demographic phenomena.

They add that population growth is another basic cause for the urbanization. According to United Nations (2006) projections for the period 2005 - 2030, world population will grow at a $1.78 \%$ average annual rate. Consequently according to this forecast there will be almost 5 billion urban dwellers by 2030 . The greater pace of urbanization is now happening in Africa and Asia; well before 2030, more than half of all people in these regions will live in urban areas.

Therefore, objective of this paper is to empirically analyze the determinants, and identify the causes and consequences of urbanization in Pakistan

\section{Significance of Study}

Little attention has been given to this burning issue to find out the macroeconomic determinants of urbanization. This study aims at addressing the urbanization problem in the light of literacy rate, economic growth, energy demand, and unemployment in macroeconomic perspective.

Studies are available in the literature that have addressed the above noted macro problems in both developing and developed countries (Lucas, 2004; Cohen, 2006; Olorunfemi, 2014; Yue-Jun et al., 2015). These studies have examined the issues of urbanization from different perspective, methodology, data and countries and have reported different results. The results, conclusions and policy recommendation are difficult to be applied to Pakistan because socio-economic- political, geographical, demographic, law and order conditions differ significantly in Pakistan. Studies, have also been done in Pakistan (Shahbaz et al., 2010; Farah et al., 2012; Ahmad et al., 2013; Afzal and Awais, 2014). These studies have added valuable input to the urbanization issue in Pakistan.

The migration from rural to urban areas created many problems for the city dwellers and government. Most prominent problems are: education, health, transportation, law and order. Karachi is the most conspicuous example of negative effects of urbanization. Muslims migrated to Pakistan from the neighbor provinces of UP, Punjab, Delhi, and others provinces; most of them settled in Karachi, though a sizeable body of migrants also settled in Lahore, Peshawar and other big urban centers of the country.

According to Alam (2005) urbanization in Sindh was a major environmental issue, as 48.9 per cent of the province population resided in urban areas. Karachi alone contained 63 percent of Sindh's urban population. A large housing demand-supply gap had resulted in the development of katchiabadis. Pakistan pursued vigorous import substitution industrialization (IS) in order to transform the economy from a predominant agricultural to a fast growing industrial economy. According to Afzal (2011) at the time of partition, Pakistan's industrial base was both narrow and weak and inherited only $10 \%$ of the total establishments in the undivided India. Therefore early policy makers of Pakistan opted for IS industrialization in 1950s. This strategy was instrumental in generating employment opportunities because industries were set up in urban centers notably Karachi. People from other parts of the country flocked to Karachi that immensely increased Karachi population.

Today population of Karachi far exceeds the population of several countries. Consequently urbanization is one of the major causes of social unrest and catastrophic law and order situation obtaining in Karachi. The similar situation also prevails in Lahore, Peshawar, and Quetta. Urbanization has also adverse impact on the agricultural sector of the country, because high rate of urbanization causes labor force to shift to the industrial sector which can affect the production capacity of the agriculture sector. And how the administration accommodates the army of migrants in the wake of severe scarcity of water, transport, hospitals, energy, housing etc is a big question mark.

Therefore it is desirable to undertake a serious study in macroeconomic context to address the urbanization issue. This study may help in the formulation of sound policies associated with the urbanization.

\section{Literature Review}

Sajor (2001) is of the view that extraordinary industrial wages in urban areas are one of the main charms for rural people. Migration into urban centers will continue as long as they believe urban wages to exceed their present rural wages. According to Preston (1979) urbanization is a dynamic process in which the growth rate of the population living in urban areas increases over time. Urbanization occupies a confusing position. It is recognized as fundamental to the multi-dimensional structural transformation that low-income rural societies undergo to modernize and to join the ranks of middle- and high-income countries.

Lucas (2004) explicitly considers how urbanization affects the growth process primarily through the enhanced flow of ideas and knowledge attributable to agglomeration in cities. Yue-Jun et al. (2015) investigated the relationship between $\mathrm{CO}_{2}$ emission and urbanization in China for the period 1980-2013 and concluded that the urbanization was promoting the carbon emission for the long term. Hytenget (2011) found the relationship between the urbanization and GDP per capita in sub-Saharan Africa for 47 countries. The results reveal that increase in growth rate of urbanization will also increase the growth of GDP per capita.

Elgin and Oyvat (2013) results indicate that there is an inverted-U connection among informality and the level of urbanization, at the early stages. Informal sector grows the urbanization due to numerous pull and push factors however; it tends to fall in the latter stages. Olorunfemi (2014) explored the relationship between the urbanization, employment, population growth, manufacturing industries, transportation and investment for Nigeria and concluded that export, unemployment among job seekers, manufacturing industries in the urban centers, transportation and investment caused urbanization to increase

Sheng et al. (2017) examined the impact of urbanization on energy consumption and efficiency for the panel of 78 countries. Results show that process of urbanization leads to significant increase in the both optimal and actual energy consumption, but a decrease in efficiency of energy consumption. In addition, they find that the degree to 
which energy inefficiency associates with urbanization is greater in countries with higher gross domestic product per capita. Topcu and Girgin (2016) examined the impact of urbanization on energy demand for a panel of eleven Middle Eastern countries over the period 1990-2012 and concluded that a 1\% increase in urbanization leads to a $0.49 \%$ increase in energy demand in the long-run.

\subsection{Studies in Pakistan}

Ahmed and Sirageldin (1994) examined the effect of migration on earnings of the internal migrants in Pakistan. The results showed earnings of migrants improved over the time after the migration to urban centers from the rural areas.

Khan and Shenaz (2000) studied the decision of migration to urban centers to study the effects of human capital, demographic and region of residence variables on the probability to migrate.Memon (2005) found that province of Punjab was the main source of internal migration and net inflow of internal migration was only in the province of Sindh. Shahbaz et al. (2017) examined the relationship between urbanization and energy use in Pakistan

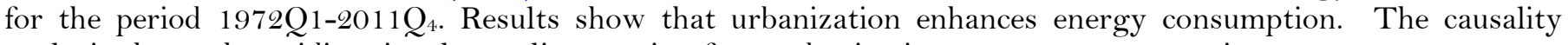
analysis shows the unidirectional causality running from urbanization to energy consumption.

Ahmad et al. (2013) investigated the internal migration determinants in Pakistan for the period $2010-2011$. Logistic regression was used to identify the impact of female education and other factors on internal migration. The results show that education has positive and significant effect on migration for both males and females, which implies that migration is a human capital investment.

\section{Model and Data}

\subsection{Model}

A number of studies have been done in Pakistan as well as abroad as reviewed above on the determinants of urbanization. These studies have addressed the issue according to their own approach, methodology, and data as country situation demanded. Keeping in view the issues under discussion, the study uses the following model according to the circumstance obtaining in Pakistan, since countries differ on the incidence of the above issue due to different socio, economic and political factors. In Pakistan urbanization has become administrative failure, as well as economic. The study will explore the major determinants and their relationship to fast growing urbanization.

Following the literature as reviewed above, the following model of determinants of urbanization is specified;

$$
\mathrm{Y}=\beta_{0}+\beta_{1} \mathrm{X}_{1} \beta_{2} \mathrm{X}_{2}+\beta_{3} \mathrm{X}_{3+} \beta_{4} \mathrm{X}_{4}+\beta_{5} \mathrm{X}_{5}+\varepsilon
$$

Where,

$\mathrm{Y}=\%$ of population living in urban areas

$\mathrm{X}_{1}=\%$ of unemployed population

$\mathrm{X}_{2}=$ education $=\%$ of literacy rate

$\mathrm{X}_{3}=\mathrm{PCGDP}=$ per capita GDP growth

$\mathrm{X}_{4}=$ age structure of population

$\mathrm{X}_{5}=$ supply of civil amenities and energy

$\varepsilon=$ error term

Above model is estimated by OLS (ordinary least squares) since the sample size is moderate.

4.2. Data

The period of the study is 2001-2016.

$\mathrm{Y}=$ Urbanization $=\%$ of population living in urban areas of Pakistan (World Bank, 2017)

$\mathrm{X}_{1}=$ Unemployment $=\%$ of total labor force (World Bank, 2017)

$\mathrm{X}_{2}=$ literacy rate $=\%$ literate population from the total population (GOP Economic Survey 2001-2001, 2005-2006 and 2016-2017).

$\mathrm{X}_{3}=\mathrm{GDP}(\mathrm{GOP}$, Economic Survey (various Issues)

$\mathrm{X}_{4}=$ Age structure 15-64 (World Bank, 2017)

$\mathrm{X}_{5}=$ energy consumption since data on supply of civil amenities were not available and therefore, energy consumption was used (World Bank, 2017)

\section{Empirical Results}

Table-1. OLS Results: $X=\beta_{0}+\beta_{1} X_{1} \beta_{2} X_{2}+\beta_{s} X_{s}+\beta_{3} X_{i}+\beta_{5} X_{s}+\varepsilon$

\begin{tabular}{|c|c|c|c|c|}
\hline Variable & Coefficient & Std. Error & t-Statistic & Prob. \\
\hline $\bar{C}$ & 23.46 & 8.56 & 2.74 & 0.013 \\
\hline $\mathrm{X}_{1}$ & -0.37 & 0.10 & -3.54 & 0.002 \\
\hline $\mathrm{X}_{2}$ & 0.32 & 0.07 & 4.68 & 0.0001 \\
\hline $\mathrm{X}_{3}$ & \begin{tabular}{|l|}
0.06 \\
\end{tabular} & 0.04 & 1.42 & 0.1698 \\
\hline $\mathrm{X}_{4}$ & \begin{tabular}{|l|}
0.16 \\
\end{tabular} & 0.18 & 0.90 & 0.3851 \\
\hline $\mathrm{X}_{5}$ & \begin{tabular}{|l|}
0.01 \\
\end{tabular} & 0.002 & 3.58 & 0.0018 \\
\hline \multicolumn{5}{|c|}{$\begin{array}{l}\mathrm{R}^{2}=0.90, \quad \mathrm{DW}=2.10, \quad \mathrm{~F}=372.24(0.000) \\
\text { Where, } \\
\mathrm{Y}=\% \text { of population living in urban areas } \\
\mathrm{X}_{1}=\% \text { of unemployed population } \\
\mathrm{X}_{2}=\text { education= }=\text { of literacy rate } \\
\mathrm{X}_{\mathrm{s}}=\text { PCGDP }=\text { per capita GDP growth } \\
\mathrm{X}_{4}=\text { age structure of population } \\
\mathrm{X}_{5}=\text { supply of civil amenities and energy } \\
\varepsilon=\text { error term }\end{array}$} \\
\hline
\end{tabular}


OLS results are given in Table 1 . The sign of the unemployment $\left(\mathrm{X}_{1}\right)$ is not unexpected. The coefficient is negative and significant. An increase in unemployment is most likely to discourage urbanization. Afzal (2009) argues that population density increases at a place where employment opportunities increase. When employment opportunities are tending to fall in urban centers, rural people do not see incentive to migrate to urban areas. 1-unit increase in unemployment will decrease urban population (Y) by 0.37 units.

Similarly the coefficient of education $\left(\mathrm{X}_{2}\right)$ is positive and significant implying that increase in literacy is another decisive factor that has significant impact on increasing urban population. Since employment opportunities are concentrated in urban centers, educated youth find adequate attraction in seeking employment in the said cities that in turn swells the population of these cities. This result visibly suggests that if employment situation in rural areas is not improved, the literate youth will not cease to migrate to cities that implicitly carry several negative effects. Education, housing, transportation, and law and order situation are the most conspicuous problems associated with urbanization. In addition to these common problems, these cities have also become a security threat. Karachi, Lahore, Peshawar and Quetta situation bears this out.

The per capita GDP growth $\left(\mathrm{X}_{3}\right)$ coefficient is positive and not significant. This means that per capita GDP growth also positively influences the growth in urban population, though it is not significant. When $\mathrm{X}_{3}$ increases, this serves as an incentive to attract rural population to migrate. Expectation of earning higher income is one of the reasons for migration (Todero and Smith, 2012). It is the high wage rate in USA, Canada, Australia, Europe and Middle Eastern countries that causes migration of skilled and unskilled labor from developing countries to immigrate to these countries. Several millions Pakistani work abroad and the remittances provide greater support to Pakistan's economy.

Age structure $\left(\mathrm{X}_{4}\right)$ is still another factor that is instrumental in increasing urban population. Afzal and Awais (2014) have reported that rural-urban composition has changed over the years. Fall in rural population and rise in urban population not only shows increase in population but also rising trend of migration to urban centers. Relative and absolute size of Karachi, Lahore, Peshawar and other cities have risen distressingly due to rapid population growth. They added that more than 40\% population in Pakistan falls between 9-24 years in the agestructure composition. Dramatic social and economic changes have caused fast urbanization and the appearance of mega cities. Age-structure though not significant, is positive suggesting that age-structure is also an important determinant of migration and urbanization. It is an open secret that generally young persons have gone to USA, Canada, Australia, Europe and the Middle Eastern countries in search of better jobs and high wage rate.

Energy use $\left(\mathrm{X}_{5}\right)$ includes diverse sources (oil, gas, electricity,) and its use has become pervasive and irresistible and this use increases with the growth in population. Rural-urban migration adds fuel to the fire. That is why its coefficient is positive and significant. Since urban centers face relatively less load-shedding, people also migrate to big cities to minimize the load-shedding suffering. Significant F-statistic shows that all the underlying variables play a part in influencing the urban population.

\subsection{Specification and Diagnostic Tests}

To check the statistical soundness and validity of the above estimated equation, specification and diagnostic tests were computed by Eviews 8 which have been presented below. These tests are routinely computed by econometric software and the underlying theory of these tests is provided in the standards econometrics text books.

Table-2. Ramsey Reset, LM and JB test Results

\begin{tabular}{l|l|l|l}
\hline Test & Coefficients & Test-statistics & Results \\
\hline Ramsey reset & 0.022 & $\mathrm{~F}(1,19)=0.88$ & Insignificant \\
\hline LM Test & 0.160 & $\mathrm{~F}(2,18)=0.85$ & Insignificant \\
\hline JB Test & 0.3695 & $\chi^{2}=0.83$ & Insignificant \\
\hline & & & \\
\hline
\end{tabular}

All results are insignificant (Table 2) suggesting no-specification bias (Ramsey reset test) and absence of serial correlation (LM Test). Insignificant JB test (Normality) indicates that residuals follow the normal distribution. This means that the estimated equation is statistically sound and reliable. Similarly Heteroscedasticity test results (Table 3) are insignificant showing absence of Heteroscedasticity that also supports statistical reliability of the estimated equation.

Table-3. Heteroscedasticity Test Results

\begin{tabular}{l|l|l|l}
\hline Test & Coefficients & Test-statistics & Results \\
\hline Breusch-Pagan-Godfrey Test & 0.80 & $\mathrm{~F}(5,19)=0.51$ & insignificant \\
\hline White Test & 0.65 & $\mathrm{~F}(19,6)=0.77$ & Insignificant \\
\hline
\end{tabular}

Table-4. Redundant Variables Test result

\begin{tabular}{l|l|l|l|l}
\hline Variable & Statistics & Value & df & probability \\
\hline $\mathrm{X}_{1} \mathrm{X}_{4}$ & F-statistics & 0.44 & $(2,20)$ & 0.64 \\
\hline $\mathrm{X}_{1}$ & F-statistics & 0.728594 & $(1,20)$ & 0.4034 \\
\hline $\mathrm{X}_{4}$ & F-statistics & 0.373361 & $(1,20)$ & 0.5481 \\
\hline
\end{tabular}

Table 4 shows redundant variables test results based on F-statistics. Results are insignificant implying that neither of the selected variables $\left(\mathrm{X}_{1}, \mathrm{X}_{4} ; \mathrm{X}_{1}\right.$ and $\left.\mathrm{X}_{4}\right)$ is redundant. $\mathrm{X}_{1}$ (\% of unemployed people) and age-structure $\left(\mathrm{X}_{4}\right)$ are relevant variables that do influence the urbanization process. Variance Inflation Factors have been reported in Table 4.5. Except one, other VIF are less than 10 showing absence of multicollinearity. 
Table-5. VIF test Results (Multicollinearity)

\begin{tabular}{l|l|l|l}
\hline variables & Coefficients variance & Uncenterd VIF & Centerd VIF \\
\hline $\mathrm{C}$ & 73.32408 & 22019.84 & NA \\
\hline $\mathrm{X}_{1}$ & 0.010997 & 11286.84 & 3.391711 \\
\hline $\mathrm{X}_{2}$ & 0.004606 & 3532.026 & 19.05576 \\
\hline $\mathrm{X}_{3}$ & 0.001748 & 3.356984 & 1.669588 \\
\hline $\mathrm{X}_{4}$ & 0.033790 & 32623.91 & 8.16457 \\
\hline $\mathrm{X}_{5}$ & $1.65 \mathrm{E}-05$ & 1083.880 & 4.54216 \\
\hline
\end{tabular}

\section{Conclusions}

History shows that human population has been moving from one city to another or from country to another due to social, economic, political and religious reasons. Migration is a global phenomenon and its dynamics and determinants change over time. Urbanization and growth go together; no country has ever reached middle-income status without a significant population shift into cities. Urbanization has strong association with unemployment, economic growth, poverty, infrastructure, crimes, health, socio-economic conditions and education. In 2050, most of the urban population of the world will be concentrated in Asia (52\%) and in Africa (21\%). A simple and modest model based on four macro-variable (unemployment, literacy, age-structure, per capita income) provided reasonable results.

An increase in unemployment is most likely to discourage urbanization. When employment opportunities are tending to fall in urban centers, rural people do not see incentive to migrate to urban areas. Literacy is another decisive factor that has significant impact on increasing urban population. Since employment opportunities are concentrated in urban centers, educated youth find adequate attraction in seeking employment in the said cities that in turn swells the population of these cities. Per capita GDP growth also positively influences the growth in urban population, though it is not significant.

Age structure is instrumental in increasing urban population. It is well known fact that generally young persons have gone to USA, Canada, Australia, European and the Middle Eastern countries in search of better jobs and high wage rate. Energy use increases with the growth in population and its use has becomes pervasive and irresistible and rural-urban migration adds fuel to the fire. Specification and diagnostics test supported the model which reveals appropriateness and statistical soundness of the model. Serious heed is paid to delimitation of cities to make them manageable and governable. Agriculture is provided sufficient resources to discourage migration to cities.

\subsection{Policy Implications}

1. Many cities of Pakistan are overburdened and overcrowded due to high population growth and rapid pace of urbanization. The most crucial and implicit problem is the absence of delimitation of the urban centers. It is dire need of the hour that serious heed is paid to delimitation of cities to make them manageable and governable

2. Rural areas are developed by allocation of sufficient resources for agriculture that is likely to discourage migration to big cities and this policy may save the abundant infrastructure cost

3. There is a need to pay a special attention to the basic necessities like education, health food, housing and water in the rural areas

\section{References}

Afzal, M., 2009. Population growth and economic development in Pakistan. Open Demography Journal, 2(1): 1-7. Available at: https://doi.org/10.2174/1874918600902010001.

Afzal, M., 2011. Exports and economic growth in Pakistan: Historical and empirical evidence. Germany: AV Akademikerverlag.

Afzal, M. and S. Awais, 2014. Population and poverty nexus in Pakistan. Journal of Independent Studies and Research, 12(2): 63-75.

Ahmad, N., A. Akram and H. Hussain, 2013. Determinants of internal migration in Pakistan. The Journal of Commerce, 5(3): 32-42.

Ahmed, A.M. and I. Sirageldin, 1994. Internal migration, earnings, and the importance of self-selection. The Pakistan Development Review, 33(3): 211-227. Available at: https://doi.org/10.30541/v33i3pp.211-227.

Alam, M., 2005. Karachi: Unplanned urbanization destroying environment: IUCN report on Sindh. Available from https://www.dawn.com/news/141855.

Arif, G.M. and S. Ibrahim, 1998. The process of urbanization in Pakistan, 1951-81.The Pakistan Development Review, 37(4): 507-522. Available at: https://doi.org/10.30541/v37i4iipp.507-522.

Cohen, B., 2006. Urbanization in developing countries: Current trends, future projections, and key challenges for sustainability. Technology in Society, 28(1-2): 63-80. Available at: https://doi.org/10.1016/j.techsoc.2005.10.005.

Elgin, C. and C. Oyvat, 2013. Lurking in the cities: Urbanization and the informal economy. Structural Change and Economic Dynamics, 27(C): 36-47. Available at: https://doi.org/10.1016/j.strueco.2013.06.003.

Farah, N., M.I. Zafar and N. Nawaz, 2012. Socio-economic and cultural factors affecting migration behavior in District Faisalabad, Pakistan. Pakistan Journal of Life \& Social Sciences, 10(1): 28-32.

Hussain, I., 2014. Urbanization in Pakistan. Dr.Ishrat Hussan /drop box/Articles/2014

Hytenget, E., 2011. The impact of urbanization on GDP per capita: A study of Sub-Saharan Africa. Available from https://www.google.com.pk/search.

Jalil, H.H. and M.M. Iqbal, 2010. Urbanization and crime: A case study of Pakistan. Pakistan Development Review, 49(4II): 741-755. Available at: https://doi.org/10.30541/v49i4iipp.741-755.

Kasarda, J.D. and E.M. Crenshaw, 1991. Third world urbanization: Dimensions, theories, and determinants. Annual Review of Sociology, 17(1): 467-501. Available at: https://doi.org/10.1146/annurev.soc.17.1.467.

Khan, A.H. and L. Shenaz, 2000. Determination of internal migration: Evidence from the LFS 1996-97. The Pakistan Development Review, 39(4): 695-712. Available at: https://doi.org/10.30541/v39i4iipp.695-712.

Lucas, J.R.E., 2004. Life earnings and rural-urban migration. Journal of Political Economy, 112(S1): S29-S59. Available at: https://doi.org/10.1086/379942.

Memon, R., 2005. Determinants and trends of internal migration in Pakistan. Institute of Developing Economies. IDE Discussion Papers No. 72 .

Olorunfemi, S., 2014. Determinants of urbanization in Nigeria: Implication for sustainable development. International Journal of Technical Research and Applications, 2(4): 50-57.

Preston, S.H., 1979. Urban growth in developing countries: A demographic reappraisal. Population and Development Review, 5(2): 195-215. Available at: https://doi.org/10.2307/1971823. 
Sajor,

E., 2001. Available

from

http://water.tkk.fi/wr/tutkimus/glob/publications/Haapala/pdffiles/URBANIZATION\%20AND\%20ENVIRONMENT.pdf [Accessed 02-04-17].

Shahbaz, M., N. Amir and M.S. Shabir, 2010. Urbanization and poverty reduction: A case study of Pakistan. IUP Journal of Infrastructure, 8(4): 23-37.

Shahbaz, M., A. Chaudhary and I. Ozturk, 2017. Does urbanization cause increasing energy demand in Pakistan? Empirical evidence from STIRPAT model. Energy, 122(C): 83-93. Available at: https://doi.org/10.1016/j.energy.2017.01.080.

Sheng, P., Y. He and X. Guo, 2017. The impact of urbanization on energy consumption and efficiency. Journal of Energy and Environment, 28(7): 673-686. Available at: https://doi.org/10.1177/0958305x17723893.

Todero, P. and S.C. Smith, 2012. Economic development. New York: Adison-Wisley.

Topcu, M. and S. Girgin, 2016. The impact of urbanization on energy demand in the Middle East. Journal of International and Global Economic Studies, 9(1): 21-28.

United Nations, 2006. World urbanization prospects: The 2006 revision.

United Nations, 2014. World Urbanization Prospects, New York.

World Bank, 2017. World development indicators. Washington D.C

Yue-Jun, Z., W.-C. Yi and B.-W. Li, 2015. The impact of urbanization on carbon emission: Empirical evidence in Beijing. Energy Procedia, 75: 2963-2968. Available at: https://doi.org/10.1016/j.egypro.2015.07.601. 